- FINANSE I PRAWO FINANSOWE.

- Journal of Finance and Financial Law $•$

Czerwiec/June 2018 • vol. 2(18): 25-36

https://doi.org/10.18778/2391-6478.2.18.03

\title{
SPOŁECZNA ODPOWIEDZIALNOŚĆ BIZNESU BANKÓW W ŚWIADOMOŚCI STUDENTÓW LUBELSKICH UCZELNI
}

\author{
Izabela Joanna Kudlak \\ Wydział Prawa i Administracji \\ Uniwersytet Marii Curie Skłodowskiej w Lublinie
}

\begin{abstract}
Streszczenie
Współcześnie CSR - Społeczna odpowiedzialność biznesu (ang. Corporate Social Responsibility) - jest kluczowym elementem działalności strategicznej liczących się przedsiębiorstw. Banki, którym zależy na poprawie bądź utrzymaniu dobrego wizerunku, starają się aktywnie promować swoje działania wykorzystujące narzędzia CSR. Celem artykułu jest zbadanie znajomości pojęcia społecznej odpowiedzialności biznesu w banku wśród studentów, którzy studiują na lubelskich uczelniach. Artykuł zawiera analizę ankiet przeprowadzonych wśród badanej grupy oraz wnioski autora związane z poruszaną tematyką.
\end{abstract}

Słowa kluczowe: społeczna odpowiedzialność biznesu, studenci lubelskich uczelni, znajomość pojęcia, bank.

JEL Class: D21, L21, M14. 


\section{WPROWADZENIE}

Współcześnie CSR - Społeczna odpowiedzialność biznesu (ang. Corporate Social Responsibility) - ma ogromne znaczenie dla działalności przedsiębiorstw. Banki również stosują narzędzia CSR i bardzo często publikują raporty je przedstawiające. Mimo to nadal świadomość społeczna zagadnienia jest niewielka. Celem artykułu jest zbadanie stopnia znajomości pojęcia społecznej odpowiedzialności biznesu w banku wśród lubelskich studentów. Artykuł analizuje zakres wiedzy tej grupy interesariuszy banków, sprawdzając tym samym, w jakim stopniu przyswoili oni publikowane dla nich informacje. Zainteresowaniem autora tekstu jest świadomość społeczeństwa w zakresie poruszanej tematyki.

\section{EWOLUCJA POJĘCIA I ZNACZENIA SPOŁECZNEJ ODPOWIEDZIALNOŚCI BIZNESU}

\subsection{Historia i rozwój społecznej odpowiedzialności biznesu}

Systematyczny rozwój gospodarczy i społeczny, wzrost konkurencji na rynkach i dążenie do maksymalizacji zysków ekonomicznych sprawiły, że przedsiębiorstwa coraz silniej konkurują o pozyskiwanie nowych i utrzymanie obecnych klientów. CSR wywodzi się od społecznej etyki biznesu, której rozwój miał miejsce w latach sześćdziesiątych XX wieku w Stanach Zjednoczonych. Pierwszy kodeks dobrych praktyk powstał w 1977 roku i był skierowany do amerykańskich przedsiębiorców w Republice Południowej Afryki. Kodeks ten zabraniał przedsiębiorcom m.in. dyskryminacji rasowej pracowników [Bernat 2009: 23-24]. Początkowo za sprawą Miltona Friedmana uważano, że społeczna odpowiedzialność dotyczy wyłącznie jednostek, natomiast odpowiedzialność firm jest ograniczona do zapewnienia zysku udziałowcom [Friedman 1970]. Zgodnie z tym uważano, że przedsiębiorstwo nie ma wpływu na społeczeństwo, środowisko czy politykę. W kolejnych latach koncepcja ta była wielokrotnie podważana, uznano bowiem, że przedsiębiorstwo powinno działać również w interesie społecznym. Głoszono, że przedsiębiorstwo nie powinno być tworzone tylko dla zysku, lecz również w celu rozwoju dobra publicznego i otoczenia społecznego. W latach następnych CSR rozwijał się wraz z rozwojem demokracji i kolejne przedsiębiorstwa wprowadzały jego wytyczne. Pojęcie społecznej odpowiedzialności biznesu ewoluowało na przestrzeni lat, co przedstawia rys. 1. 


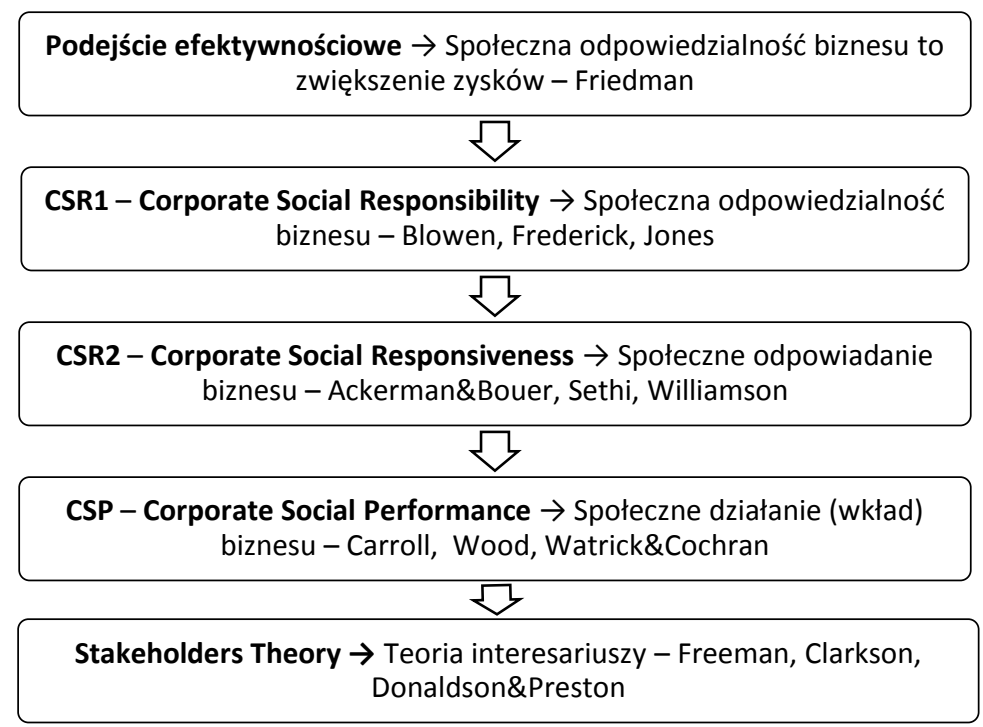

Rys. 1. Ewolucja pojęcia społecznej odpowiedzialności biznesu

Źródło: Paliwoda-Matiolańska [2009: 66].

Obecnie CSR jest coraz bardziej rozpowszechniony i stosowany przez kolejne firmy. Również sektor bankowy ukierunkował swoje działania na kreowanie wizerunku firmy społecznie odpowiedzialnej. Od dwóch dekad CSR jest znaczącym elementem marketingu bankowego. Praktycznie wszystkie większe banki w Polsce wprowadzają narzędzia CSR, jednak niewiele z nich przedstawia swoją działalność w postaci corocznych raportów CSR. Coraz częściej oczekuje się, że przedsiębiorstwa będą uwzględniać obok zysku również aspekty ekologiczne i dążyć do rozwiązywania problemów społecznych. Podejście takie nazywane jest społeczną odpowiedzialnością biznesu [Werenowska 2015: 435-436].

\subsection{Definicja społecznej odpowiedzialności biznesu}

Idea społecznej odpowiedzialności biznesu nawiązywała do odmiennych uzasadnień i była interpretowana na wiele sposobów. Współcześnie istnieje wiele jej definicji. Według J. Adamczyka, CSR jest odpowiedzialnością za zobowiązania przyjmowane przez przedsiębiorstwo $\mathrm{w}$ wyniku jego funkcjonowania w społeczeństwie. Taka odpowiedzialność powstaje wtedy, gdy społeczeństwo niejako narzuca przedsiębiorstwu określony sposób działania. Ocena moralna działalności przedsiębiorstwa w opinii podmiotów nią zainteresowanych kreuje 
realizację interesów właścicieli czynników produkcji [Zakrzewska-Bilawska (red.) 2012: 503]. Natomiast Komisja Europejska traktuje CSR jako koncepcję, według której przedsiębiorstwa dobrowolnie biorą pod uwagę aspekty społeczne i ekologiczne w swoich działaniach handlowych oraz w kontaktach ze swoimi interesariuszami [Bernat 2009: 26].

\subsection{Istota społecznej odpowiedzialności biznesu}

Najczęściej powoływanym modelem CSR jest model sformułowany przez A.B. Carroll. Według niego społeczną odpowiedzialność można podzielić na: odpowiedzialność filantropijną, etyczną, prawną i ekonomiczną. W ramach odpowiedzialności filantropijnej przedsiębiorstwo angażuje się i wspiera społeczność lokalną. Odpowiedzialność etyczna dotyczy unikania przez przedsiębiorstwo niepożądanych zachowań. Prawny rodzaj odpowiedzialności obejmuje przestrzeganie prawa, ochronę praw konsumenta oraz ochronę środowiska naturalnego. Ostatnim rodzajem odpowiedzialności jest odpowiedzialność ekonomiczna, rozumiana również jako zyskowność firmy. W ramach tej odpowiedzialności przedsiębiorstwo dąży do maksymalizacji dochodów i minimalizacji kosztów [Rybak 2004: 29-30]. Społeczna odpowiedzialność biznesu wpływa na reputację. Mechanizm tego wpływu jest jednak znacznie bardziej złożony, niż początkowo sądzono, ponieważ obejmuje nie tylko oddziaływanie bezpośrednie, ale również pośrednie. Oddziaływanie pośrednie łączy CSR z atrakcyjnością produktów i usług, siłą więzi emocjonalnej między organizacją a jej interesariuszami, poziomem satysfakcji klientów, czy wynikami osiąganymi przez podmiot w sferze finansowej. Należy zwrócić uwagę, że oddziaływanie społecznej odpowiedzialności biznesu pociąga za sobą szereg sprzężeń zwrotnych. CSR wpływając pozytywnie na odczucia interesariuszy pozwala zwiększyć wynik finansowy banku, a co za tym idzie umożliwia zwiększenie społecznego zaangażowania banku [Dąbrowski 2016: 137-138].

\section{SPOŁECZNA ODPOWIEDZIALNOŚĆ BIZNESU W UJĘCIU PRAKTYCZNYM}

\subsection{Narzędzia realizacji CSR}

Przedsiębiorstwo, któremu zależy na osiągnięciu sukcesu, musi zwracać uwagę na skutki podejmowanych przez nie działań. Pomijanie tak istotnego źródła informacji można uznać za działanie nierozważne i krótkowzroczne. W dobrze rozwiniętych gospodarczo krajach uważa się, że celem firmy jest przynoszenie korzyści wszystkim grupom społecznym, nawet wtedy, gdy mogłoby się to wią- 
zać ze zmniejszeniem zysków krótkookresowych [Kopycińska 2001: 187]. Dobranie odpowiednich narzędzi jest zadaniem trudnym, ponieważ znacznie różnią się one pod względem możliwości zastosowania, rezultatów oraz skuteczności. Aby poprawnie je dobrać, należy uwzględnić m.in. wielkość podmiotu gospodarczego, zasięg i obszar funkcjonowania firmy oraz rodzaj branży i typ prowadzonej działalności, misję firmy, zasoby finansowe i kondycję ekonomiczną przedsiębiorstwa, oczekiwania i potrzeby otoczenia przedsiębiorstwa, typ i poziom szkodliwości powodowany przez funkcjonowanie przedsiębiorstwa oraz wiedzę i umiejętności osób odpowiedzialnych za prowadzenie inicjatyw CSR [Zakrzewska-Bielawska (red), 2012: 513].

Literatura wymienia cztery podstawowe narzędzia i instrumenty CSR dotyczące społeczeństwa i społeczności lokalnej. Są nimi: raportowanie społeczne, finansowanie, przygotowanie i realizacja różnych kampanii społecznych, edukacja społeczeństwa, zaangażowanie w lokalną działalność społeczną oraz wsparcie lokalnej przedsiębiorczości. Raportowanie polega na okresowej publikacji dokumentacji zawierającej informacje ekonomiczne, społeczne, środowiskowe i etyczne na temat firmy. W odróżnieniu od broszur reklamowych, raport oprócz osiągnięć firmy zawiera również jej potknięcia w danym okresie. Finansowanie, przygotowanie i realizacja różnych kampanii społecznych są inicjatywami wykorzystującymi media jako środek przekazu. Zwykle przedsięwzięcia takie angażują wiele podmiotów jednocześnie i mają na celu zmianę postaw lub zachowań określonej grupy ludzi. Przez edukację społeczeństwa rozumiemy korzystny wpływ na poziom świadomości i zrozumienia istoty poruszanych zagadnień oraz promowanie znaczenia edukacji w życiu człowieka. Natomiast zaangażowanie w lokalną działalność społeczną oraz wsparcie lokalnej przedsiębiorczości dotyczy przyczyniania się do inicjowania i długoterminowego wspierania wartościowych działań podejmowanych przez społeczność lokalną. Dotyczy również budzenia świadomości społecznej jakiegoś ważnego problemu lub grupy problemów [Zakrzewska-Bielawska (red.), 2012: 524].

\subsection{Społeczna odpowiedzialność biznesu popularnych banków na polskim rynku - MILLENNIUM BANK S.A. oraz BANK ZACHODNI WBK, GRUPA SANTANDER}

Pierwszym z analizowanych banków jest Millennium Bank S.A. Bank ten publikuje coroczne raporty CSR między innymi na swojej stronie internetowej. Wymienione poniżej działania pochodzą z raportu opublikowanego za 2015 rok [Millennium Bank, 2015]. Omawiany bank podzielił swój raport na dziewięć części. Pierwszą z nich stanowią informacje o banku. Kategoria ta wskazuje wszystkie podstawowe dane, które mogą posłużyć zdobyciu wiedzy o tej instytucji finansowej. Następną grupą są interesariusze banku. Tu raport skupia się na 
wskazaniu kanałów kontaktu z bankiem i ich częstotliwości. Takie dane umożliwiają interesariuszom zaciągnięcie informacji, jak często i w jaki sposób powinni mieć kontakt $\mathrm{z}$ instytucją.

Następną grupą jest bezpieczeństwo powierzonych środków. Tu raport wskazuje, jakie środki bank stosuje, aby zadbać o zabezpieczanie kapitału powierzanego sobie przez klientów. Działaniami CSR w tej grupie są między innymi doszkalanie pracowników, wprowadzanie najnowocześniejszych rozwiązań, przeprowadzanie audytów czy kontroli prewencyjnych.

Kolejna grupa istotna dla banku to jego klienci. Organizacja dba o zapewnienie bezpieczeństwa powierzonych środków, przestrzeganie zasad etyki $\mathrm{w}$ marketingu i w procesie sprzedaży, oferowanie dostosowanych do potrzeb klienta produktów, zapewnienie wysokiej jakości obsługi oraz dostępu do usług dla grup wykluczanych. Tutaj za działania będące przedmiotem rozważań można uznać asystę doradców w podejmowaniu decyzji finansowych czy ułatwienie komunikacji z bankiem przez różne kanały. Zwiększenie dostępu do usług dla osób z grup wykluczonych stanowi istotny element działalności banku. Osoby niepełnosprawne i starsze wymagają większej asysty, dlatego też placówki banku przygotowywane są odpowiedzialnie, by ułatwić wymienionym grupom poruszanie się po nich i udogodnić im załatwienie spraw.

Następną grupą są inwestorzy. To dla nich bank sporządza raporty ze swojej działalności i strategii. Narzędziami w tej grupie są między innymi utrzymanie wysokich standardów, a co za tym idzie obecność w RESPECT Indeks.

Partnerzy biznesowi banku są dobierani z uszanowaniem zasad etyki i troski o środowisko. Duże znaczenie dla banku ma korzystanie z usług lokalnych dostawców, co przyczynia się do ich rozwoju.

Kolejną grupę stanowią pracownicy. Ich dobór, rekrutacja i selekcja są przeprowadzanie tak, by przyczyniło się to do rozwoju firmy. Działania CSR w tym zakresie dotyczą między innymi troski o jakość stanowisk pracy, różnorodność zatrudnionych, czy umożliwienie połączenia pracy zawodowej z posiadaniem rodziny. Ważnym aspektem są również warunki pracy i dodatkowe świadczenia oferowane pracownikom, takie jak opieka medyczna, edukacja kulturalna czy sportowa.

Grupą równie istotną jest społeczeństwo. Tutaj bank swoje działania CSR kieruje na edukację zarówno dzieci, jak i dorosłych, wspiera inicjatywy społeczne i liczne wolontariaty. Takie zachowanie przyczynia się do wzrostu świadomości społecznej i aktywizacji otoczenia banku.

Ostatnim, ale nie mniej istotnym obszarem jest środowisko naturalne. Działania banku w tym zakresie skupiają się na minimalizacji negatywnego wpływu na środowisko poprzez racjonalną gospodarkę materiałami, monitorowanie zużycia wody, energii i paliw, wprowadzanie prośrodowiskowych rozwiązań w działalności oraz udział w akcjach edukacyjnych [Millennium Bank, 2015]. 
Drugim $\mathrm{z}$ analizowanych banków jest Bank Zachodni WBK, Grupa Santander. W przypadku tej instytucji finansowej dane pochodzą również z raportu CSR z roku 2015 [Bank Zachodni WBK Grupa Santander, 2015]. Grupa Santander swoje działania z zakresu CSR podzieliła na 5 grup. Są nimi informacje o banku, pomoc klientom w rozwoju, pomocna i rozwojowa organizacja, wspieranie społeczności lokalnej i otoczenia $\mathrm{w}$ rozwoju oraz informacje o raporcie $\mathrm{i}$ interesariuszach.

Pierwsza grupa dostarcza informacji na temat zakresu działalności banku i priorytetów, jakimi ta organizacja się kieruje. Rozwój swojego otoczenia i przejrzystość informacji bank uważa za działanie odpowiedzialne społecznie.

Druga grupa danych dostarcza informacji, jak dokładnie bank przyczynia się do realizacji swoich celów. Działaniami wykorzystującymi narzędzia CSR są oferowanie usług przejrzystych i efektywnych, zwiększenie dostępności banku poprzez różne kanały kontaktu wykorzystujące rozwój elektroniki, utrzymanie wysokich standardów bezpieczeństwa czy zróżnicowanie usług i programów w celu dostosowania do różnych grup społecznych. Swoje działania bank kieruje na motywowanie do rozwoju i ułatwienie rozpoczęcia i prowadzenia dorosłego życia klientów indywidualnych oraz pomoc klientom korporacyjnym $\mathrm{w}$ osiągnięciu ich celów. Nowe produkty oferowane przez bank zwiększają innowacyjność, mobilność i wiedzę ich użytkowników.

Trzecia grupa skupia się na utrzymaniu dotychczasowych i pozyskaniu nowych pracowników, którzy poprzez liczne możliwości rozwoju zostaną w organizacji i przyczynią się do realizacji jej celów. Przykładami społecznie odpowiedzialnych działań są tu utrzymywanie różnorodności zatrudnienia, motywacja do zdobywania nowej wiedzy i umiejętności, liczne szkolenia czy stworzenie przyjaznego miejsca pracy. Bank zapewnia swoim pracownikom opiekę medyczną, ułatwienia dla pracowników zakładających rodziny, szkolenia z pierwszej pomocy czy współpracy. Organizacja kieruje się etyką zawodową i przyjazną pracownikom kulturą organizacyjną. Ekologia stanowi ważny aspekt w pozyskiwaniu surowców potrzebnych do działalności banku.

Celem banku jest budowanie społeczeństwa obywatelskiego i, aby to osiągnąć, instytucja ta finansuje liczne programy edukacyjne, konkursy specjalistyczne o randzie międzynarodowej oraz ma realny wkład w kulturę przez między innymi Santander Orchestrę czy BZ WBK PRESS FOTO. Działalność Fundacji BZ WBK oraz wolontariatów, w które angażuje się bank i jego pracownicy, przyczynia się do poprawy jakości życia społeczności. Grupa Santander wspiera innowacyjne pomysły środowisk akademickich, co ułatwia życie studentów. Dzieci i młodzież mają możliwość nauki w przystępny i ciekawy sposób za pomocą projektów finansowanych przez bank. Kolejnym istotnym narzędziem jest wychodzenie naprzeciw potrzebom osób niepełnosprawnych. 
Bank za swoich interesariuszy uważa liczne grupy społeczne i swoje działania projektuje tak, by zadowolić wszystkie te grupy. Wymieniając poszczególne $\mathrm{z}$ nich klasyfikuje je w kategorie takie jak m.in. klienci indywidualni czy przedsiębiorstwa, dla każdej z tych kategorii proponując personalizowane rozwiązania [Bank Zachodni WBK Grupa Santander, 2015].

\section{ZNAJOMOŚĆ POJĘCIA CSR WŚRÓD LUBELSKICH STUDENTÓW}

Autor w celu napisania tego artykułu przeprowadził drogą elektroniczną badanie wśród grupy pięćdziesięciu studentów i studentek uczących się na pięciu największych lubelskich uczelniach. Grupa ankietowanych składała się z dwudziestu ośmiu kobiet $(56 \%)$ oraz dwudziestu dwóch mężczyzn (44\%). Większość ankietowanych - 62\% - stanowili studenci Uniwersytetu Marii Curie-Skłodowskiej. Kolejną pod względem wielkości była grupa z Politechniki Lubelskiej, która stanowiła 14\% ankietowanych. Następnie grupa z Katolickiego Uniwersytetu Lubelskiego im. Jana Pawła II, która stanowiła 10\% ankietowanych. Najmniejsze grupy pochodziły z Uniwersytetu Medycznego w Lublinie $8 \%$ oraz Uniwersytetu Przyrodniczego w Lublinie - 6\%. Grupę ankietowanych w większości stanowili studenci studiów licencjackich - 58\%. Studenci studiów magisterskich stanowili 32\%, studenci jednolitych studiów magisterskich $-6 \%$, natomiast studenci studiów inżynierskich $-4 \%$. Opisana powyżej grupa badanych miała za zadanie udzielić odpowiedzi na pytania zamknięte.

Pierwsze z pytań miało na celu zbadać, czy studenci znają znaczenie skrótu CSR. Wykres 1 przedstawia odpowiedzi respondentów.

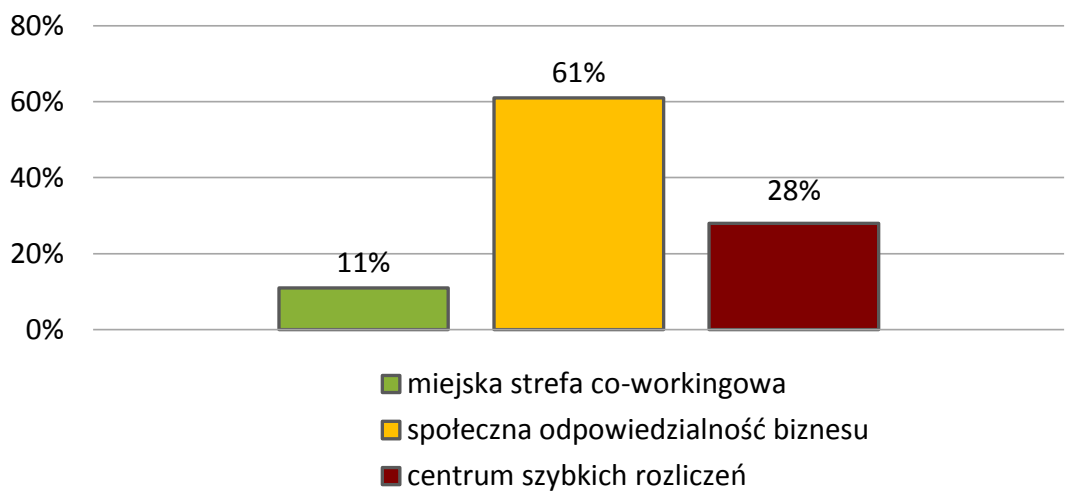

Wykres 1. Znajomość skrótu CSR wśród ankietowanych

Źródło: opracowanie własne na podstawie przeprowadzonych badań. 
Tak wysoki wskaźnik trzeciej odpowiedzi może być spowodowany sugerowaniem się rozwinięciem skrótu CSR na język polski oraz brakiem znajomości zagadnienia.

W kolejnym pytaniu autor artykułu zapytał badanych o wskazanie 3 kluczowych dla pojęcia społecznej odpowiedzialności biznesu słów. Wykres 2 prezentuje uzyskane odpowiedzi.

Taki podział wyników mógł być spowodowany ponownie sugerowaniem się, w tym przypadku odpowiedzią z poprzedniego pytania, czyli skojarzeniem szybkości z centrum rozliczeń.

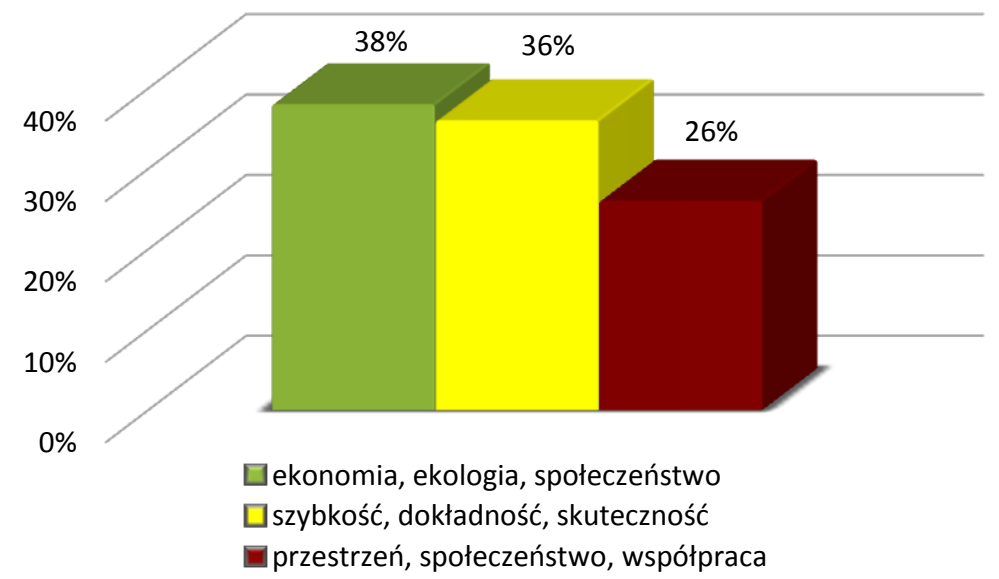

Wykres 2. Wskazania 3 kluczowych dla CSR słów

Źródło: opracowanie własne na podstawie przeprowadzonych badań.

Następne pytanie miało na celu zbadanie, czy ankietowani znają źródło zasadności stosowania społecznej odpowiedzialności biznesu. Proponowanymi odpowiedziami na pytanie „Przyjęcie CSR zależy od...”: były: „chęci przedsiębiorstwa”, ,jest narzucone konstytucją", ,jest narzucone ustawą" oraz ,jest narzucone przepisami prawa europejskiego". Znaczna większość ankietowanych wskazała poprawną odpowiedź, co przedstawia wykres 3.

Pytanie „Czy wymiana żarówek na energooszczędne wystarczy, by nazwać przedsiębiorstwo społecznie odpowiedzialnym?” uzyskało najwięcej poprawnych odpowiedzi. Aż 90\% ankietowanych uznało takie działanie przedsiębiorstwa za niewystarczające. Jedynie $10 \%$ badanych uznała wymianę żarówek na energooszczędne za działanie dostateczne. 


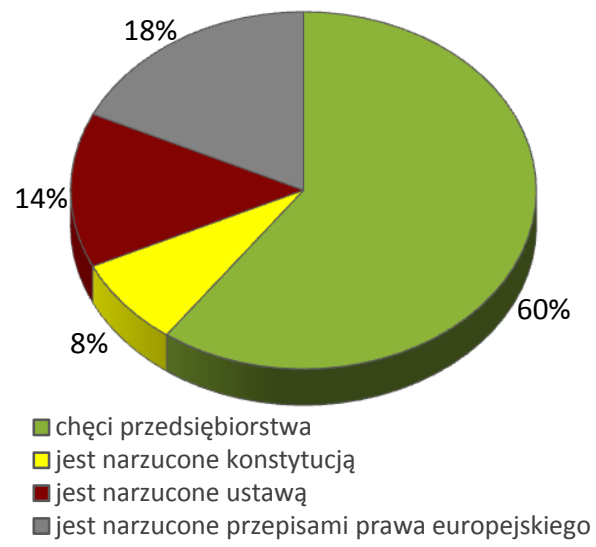

Wykres 3. Wskazanie od czego zależy przyjęcie CSR

Źródło: opracowanie własne na podstawie przeprowadzonych badań.

Dużo poprawnych odpowiedzi pojawiło się w pytaniu najbardziej złożonym. „Które z poniższych należy uwzględnić, aby poprawnie dobrać narzędzia CSR (wybierz wszystkie twoim zdaniem kluczowe)" Ankietowani mieli do wyboru 12 pozycji, z czego 8 zostało wskazanych w literaturze przedmiotu [Zakrzewska-Bielawska (red.) 2012: 513] oraz wymienionych wyżej w tymże artykule. Wykres 4 przedstawia ich odpowiedzi.

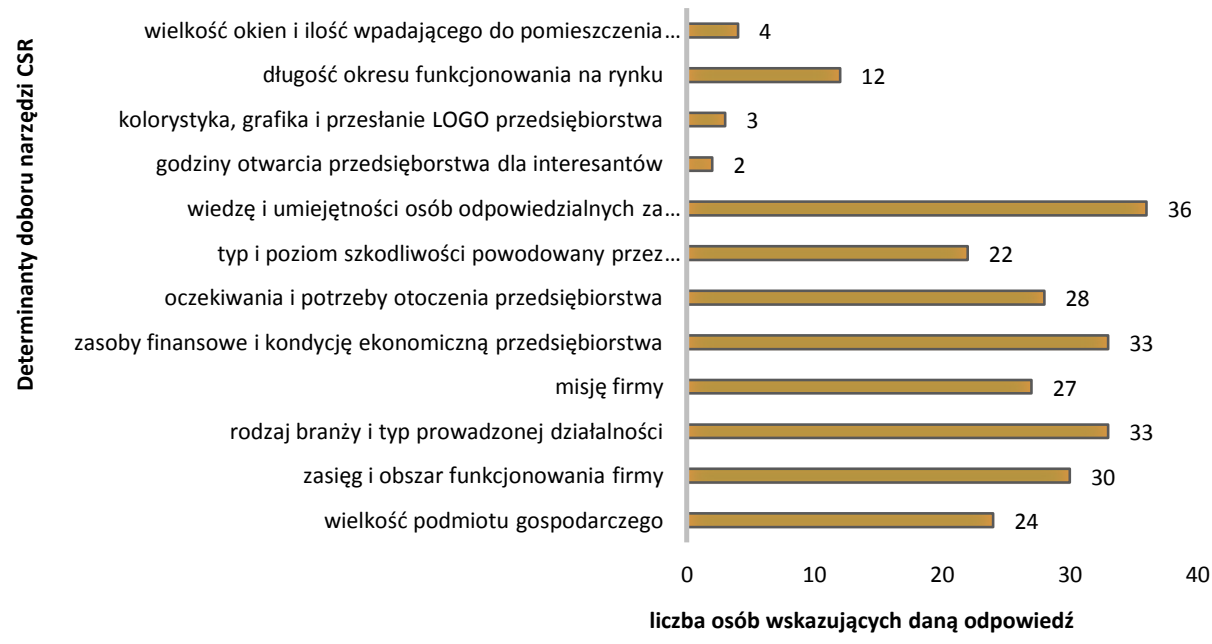

Wykres 4. Wskazania studentów w pytaniu wielokrotnego wyboru

Źródło: opracowanie własne na podstawie przeprowadzonych badań. 
Powyższe wyniki pokazują, że odsetek poprawnych odpowiedzi jest wysoki. Ankietowani jednak najczęściej zaznaczali po trzy lub cztery odpowiedzi, dlatego też powyższy wykres nie ma w żadnej pozycji wybranej $100 \%$.

Analizując wyniki przeprowadzonych badań autor artykułu uznał, że znajomość zagadnienia społecznej odpowiedzialności biznesu wśród ankietowanych studentów jest niewielka. Znaczna część z nich nie wiedziała czego dotyczy badanie i swoje odpowiedzi zaznaczała na podstawie domysłów i skojarzeń. Jeśli chodzi o dobór narzędzi, tu mimo wysokiego wskaźnika poprawnych odpowiedzi nikt $\mathrm{z}$ ankietowanych nie zaznaczył poprawnie wszystkich ośmiu oczekiwanych wskazań.

Przedstawione powyżej wyniki ankiety dowodzą, że wiedza studentów studiujących na czołowych lubelskich uczelniach z zakresu społecznej odpowiedzialności banków pozostawia wiele do życzenia. Możliwe, że znaczna część ankietowanych nie miała nigdy styczności z tematyką społecznej odpowiedzialności biznesu w instytucjach finansowych. Mimo, że prawdopodobnie większość z nich jest klientami banków, ich wiedza na temat działalności tych instytucji jest niezadowalająca. Powyższe przemyślenia sugerują, że omawiane instytucje finansowe mają wciąż wiele do zrobienia $\mathrm{w}$ zakresie informowania młodego pokolenia o swoich działaniach. Przyczynić się to może zarówno do zwiększenia świadomości ogółu, jak i, co ważne dla autora artykułu, świadomości jednostek. Bardzo istotne jest, aby młody człowiek, a w szczególności student, kończąc edukację z wykształceniem wyższym, miał świadomość działań instytucji z których korzysta bądź które w przyszłości mogą zostać jego pracodawcą. Studenci są nie tylko klientami banków, ale również stanową ogromną grupę potencjalnych pracowników. Takie ujęcie tematu pozwala bankom na analizę swojej działalności oraz wysunięcie wniosków, w jakim kierunku prowadzić swoje działania wykorzystujące narzędzia społecznej odpowiedzialności biznesu.

\section{PODSUMOWANIE}

Podsumowując, społeczna odpowiedzialność biznesu jest kluczowym elementem zarządzania i kreowania wizerunku banków. Ich działania są zauważane w społeczeństwie, jednak nie zawsze docierają do grona studentów. Grupa ankietowanych wykazała się raczej nieusystematyzowaną wiedzą w zakresie znajomości pojęcia i jego znaczenia. Ankietowani kierowali się raczej intuicją i zasadą skojarzeń niż faktyczną wiedzą w badanej tematyce. Powyższe wyniki sugerują, że banki, którym zależy na pozyskaniu klientów lub pracowników wśród lubelskich studentów powinny zwiększyć nacisk na informowanie o swoich działaniach z zakresu CSR, które obecnie w szerszej perspektywie są znacz- 
nym walorem tych instytucji finansowych. Przedstawione banki - mimo licznych działań społecznie odpowiedzialnych i uznania studentów za grupę swoich interesariuszy - nie dotarły wciąż do świadomości lubelskich studentów.

\title{
BIBLIOGRAFIA
}

Bank Zachodni WBK Grupa Santander, 2015, Raport spotecznej odpowiedzialności biznesu, Raport CSR Bank Zachodni WBK S.A.

Bernat M., 2009, Spoteczna odpowiedzialność biznesu. Wymiar konstytucyjny i międzynarodowy, Wydawnictwo Naukowe Wydziału Zarządzania Uniwersytetu Warszawskiego, Warszawa.

Dąbrowski T.J., 2016, Kształtowane reputacji banku komercyjnego. Podejście symboliczne i substancjalne, Oficyna Wydawnicza - Szkoła Główna Handlowa w Warszawie, Warszawa.

Friedman M., 1970, The Social Responsibility of Business Is to Increase its Profits, „New York Times Magazine", 13.09.1970.

Kopycińska D., 2001, Koncepcja społecznej odpowiedzialności firmy-poezja teorii i proza życia, [w:] W. Gasparski, J. Dietl (red.), Etyka biznesu w działaniu. Doświadczenia i perspektywy, Wydawnictwo Naukowe PWN, Warszawa.

Millennium Bank, 2015, Odpowiedzialny Biznes, Millennium Bank S.A.

Paliwoda-Matiolańska A., 2009, Odpowiedzialność społeczna $w$ procesie zarządzania przedsiębiorstwem, C.H. Beck, Warszawa.

Rybak M., 2004, Etyka menedżera - społeczna odpowiedzialność przedsiębiorstwa, Wydawnictwo Naukowe PWN, Warszawa.

Werenowska A., 2015, CSR jako element zarządzania wizerunkiem banku, „Studia i Prace Wydziału Nauk Ekonomicznych i Zarządzania", nr 39, t. 4, Uniwersytet Szczeciński, Szczecin.

Zakrzewska-Bilawska A. (red. nauk.), 2012, Podstawy zarzadzania. Teoria $i$ ćwiczenia, Wydawnictwo Oficyna, Warszawa.

\section{BANKS CORPORATE SOCIAL RESPONSIBILITY IN THE AWARENESS OF STUDENTS OF LUBLIN UNIVERSITIES}

\begin{abstract}
Today CSR - corporate social responsibility - is a key element of the strategic operations of meaningful companies. Banks which care about the improvement or keeping the good image are trying actively to promote their action using CSR tools. Examining the acquaintance of comprehending the corporate social responsibility at the bank amongst students which are studying at Lublin universites is a purpose of the article. The article contains the analysis of polls conducted amongst the examined group and the author conclusions with the subject matter brought up.
\end{abstract}

Keywords: corporate social responsibility, students of Lublin universities, knowledge of the concept, bank. 